\title{
ANALISIS RANGKAK SUSUT BETON TERHADAP TEGANGAN DAN LENDUTAN BERDASARKAN BEBERAPA PERATURAN PADA JEMBATAN PRATEGANG
}

\author{
Kevin Wijaya ${ }^{1}$ dan FX Supartono ${ }^{2}$ \\ ${ }^{1}$ Program Studi Sarjana Teknik Sipil, Universitas Tarumanagara, Jl. Letjen S. Parman No.1 Jakarta \\ Kevin.325160155@stu.untar.ac.id \\ ${ }^{21}$ Program Studi Sarjana Teknik Sipil, Universitas Tarumanagara, J1. Letjen S. Parman No.1 Jakarta \\ fxsupartono@stu.untar.ac.id
}

Masuk: 3-7-2020, revisi: 14-8-2020, diterima untuk diterbitkan: 4-10-2020

\begin{abstract}
Prestress losses are one of the important factors that used in prestress concrete construction design. Prestress losses generally divided into immediately losses and time dependent losses. On the process of bridge construction, the prestress losses caused by time dependent have a big influence on the deflection and stressess results that because the life services of bridges normally more than 10 years. If there are any error occurs in calculating the effect of time dependent losses, then the deflection that occurs when life service could exceed the maximum allowed deflection. Therefore, the purpose on making this thesis is to analyst how much the influences of time dependent effect (creep and shrinkage) using 3 different methods, that is ACI209.2R-08, CEB-FIB MC90 and EN1992-1-1. This bridge has total span length of 60m with rolled-joint placement and single span type. Using double cellular prestress concrete as girder. Stages of loading apply a superimposed deadload, creep and shrinkage using a interval duration of 7,30 and 10000 days. This analysit was carried out by using MIDAS 2020 software. The result of this analyist showed the deflection that occurs with the 3 different methods is quite similiar. And the deflection after construction still below the maximum allowable deflection.
\end{abstract}

Keywords : prestress concrete; prestress losses; creep; shrinkage; deflection

\begin{abstract}
ABSTRAK
Kehilangan prategang atau yang biasa disebut prestress losses adalah komponen penting dalam konstruksi menggunakan beton prategang. Prestress losses dibagi menjadi dua yaitu immediately losses dan time dependent losses. Dalam proses konstruksi jembatan, prestress losses yang diakibatkan oleh time dependent sangatlah berpengaruh terhadap lendutan dan tegangan yang dihasilkan karena umur layan jembatan biasanya berkisar hingga 10 tahun keatas, jika salah dalam memperhitungkan efek dari time dependent losses maka lendutan yang terjadi dapat melampaui batas ijin lendutan sehingga dapat menyebabkan jembatan collapse. Oleh karena itu, tujuan dari penelitian ini adalah untuk mengetahui seberapa besar pengaruh time dependent losses mengcakup creep dan shrinkage dengan menggunakan 3 metode yang berbeda yaitu ACI209.2R-08, CEB-FIB MC90 dan EN1992-1-1. Jembatan yang didesain memiliki panjang 60m dengan perletakan sendi-rol dan jenis jembatan single span. Menggunakan double cellular prestress concrete sebagai girder. Interval analisis adalah 7 hari, 30 hari dan 10000 hari. Analisis digunakan menggunakan program Midas Civil 2020. Hasil dari analisis ini menunjukkan bahwa tegangan dan lendutan yang dihasilkan dari ketiga metode relatif identik dan lendutan yang terjadi hingga 10000 hari masih dalam batas ijin.
\end{abstract}

Kata kunci : beton prategang; kehilangan prategang; rangkak; susut; lendutan

\section{PENDAHULUAN}

Jembatan adalah suatu konstruksi yang berfungsi menghubungkan dua daratan yang terputus akibat adanya rintangan, rintangan tersebut bisa berupa sungai, danau, lembah, rel kereta maupun kota. Fungsi utama jembatan itu sendiri adalah untuk memperlancar arus lalu lintas yang dimana arus kendaraan akan meningkat seiring berjalannya waktu (Supriyadi \& Setyo Muthohar, 2007). Oleh karena itu jembatan harus dibuat cukup kuat karena kerusakan dari jembatan dapat menimbulkan gangguan terhadap arus lalu lintas. Namun bukan berarti jembatan harus dibuat kokoh dan kuat berlebihan, jembatan harus tetap memenuhi aspek ekonomis dan tetap memiliki kekuatan yang baik, menggunakan mutu bahan yang tinggi dan waktu konstruksi yang cepat. Salah satu sistem yang cocok dan banyak digunakan saat ini adalah jembatan beton prategang (Prestressed bridge). 
Beton prategang adalah jenis struktur beton dengan memberi tegangan awal pada struktur dengan arah berlawanan dengan arah beban yang diberikan. Sistem prategang bekerja dengan cara menarik baja mutu tinggi atau biasa yang disebut tendon. Jenis beton yang digunakan harus bermutu tinggi ( $f c^{\prime} \geq 40 \mathrm{MPa}$ ) karena jenis tendon yang digunakan adalah baja bermutu tinggi agar beton dapat menahan gaya yang diberikan tendon. Penggunaan beton prategang dalam konstruksi jembatan semakain banyak digunakan karena dianggap memberikan kemudahaan disebabkan beton prategang memiliki dimensi yang lebih kecil dan jumlah baja yang digunakan lebih sedikit dari beton biasa. Namun permasalahan timbul dari penggunaan beton prategang yaitu adanya losses (kehilangan) yang terjadi. Losses yang terjadi sangat berpengaruh khususnya losses yang disebabkan oleh waktu (time dependent) karena jembatan pada umumnya memiliki waktu layan lebih dari 10 tahun. Jika perhitungan losses tidak dilakukan dengan benar, besar kemungkinan jembatan akan mengalami collapse akibat lendutan yang berlebihan. Maka dari itu, tugas akhir ini akan menganalisis pengaruh rangkak dan susut dengan menggunakan ketiga metode (ACI209.2R-08, CEB-FIB MC90 dan EN-1992-1-1) pada jembatan prategang.

Rumusan masalah yang akan dibahas dalam tugas akhir ini adalah bagaimana pengaruh efek rangkak dan susut dengan menggunakan metode ACI209.2R-08, CEB-FIB MC90 dan EN-1992-1-1 terhadap hasil lendutan dan tegangan. Dan apakah lendutan yang terjadi masih dalam batas lendutan ijin.

Tujuan dari penelitian ini adalah untuk mengetahui dan membandingkan sejauh mana pengaruh dari efek rangkak dan susut dengan menggunakan 3 metode terhadap tegangan dan lendutan yang terjadi.

\section{Rangkak dan susut}

\section{Rangkak}

Rangkak beton adalah nilai regangan tambahan yang terdapat pada beton yang mengalami tegangan konstan, terukur dari terjadinya tegangan elastis sampai regangan yang terjadi pada waktu tertentu. Dalam praktiknya, regangan akan bertambah besar apabila koefisien rangkak beton bertambah, namun pertambahan regangan akan berkurang seiring waktu.

Nilai rangkak dapat dipengaruhi banyak hal sangat bervariasi. Faktor yang mempengaruhi deformasi rangkak adalah:

1. Pilihan bahan dasar seperti jenis semen yang digunakan, persentase agregat kasar dan halus

2. Besarnya kadar air dan perbandingan water/cement ratio

3. Kelembaban relatif

4. Suhu beton saat pengeringan

5. Dimensi struktur, khusunya tebal dan perbandingan volum terhadap permukaan

6. umur pada waktu pembebanan

7. nilai slump

\section{Susut}

Susut adalah sifat beton yang memyebabkan mengecilnya volume beton akibat berkuranganya kadar air dan hilangnya kelembaban pada proses pengerasan. Pada dasarnya susut pada beton dibagi menjadi 2 yaitu : susut plastis dan susut pengeringan. Susut plastis adalah susut yang terjadi cepat atau sesaat setelah beton dicor. Sedangkan susut pengeringan adalah susut yang terjadi setelah beton mencapai titik keras dan proses hidrasi semen telah berakhir.

Nilai susut dinyatakan dengan Esh (regangan susut) yang dapat ditentukan oleh banyak faktor. Faktor tersebut antara lain:

1. Kadar agregat. Beton dengan kandungan agregat yang tinggi akan mengalami penyusutan volume yang semakin kecil. Dan jika semakin tinggi kadar agregatnya maka modulus elastisitas beton akan tinggi yang menyebabkan beton lebih tahan terhadap susut.

2. Faktor air semen. Semakin besar faktor $w / c$ maka susut akan semakin besar.

3. Dimensi struktur. Nilai susut akan semakin kecil jika volume struktur semakin besar. Proses terjadinya susut akan semakin lama untuk struktur yang lebih besar karena membutuhkan banyak waktu agar pengeringan merata.

4. Kondisi lingkungan. Kelembaban relatif disekitar struktur beton juga mempengaruhi nilai susut, nilai susut akan semakin kecil jika dilingkungan dengan kelembaban relatif yang tinggi. 
5. Penulangan. Beton bertulang akan mengalami susut lebih sedikit dibandingkan beton normal.

6. Jenis Semen. Susut karbonasi terjadi akibat reaksi $\mathrm{CO}_{2}$ di udara dengan yang ada dipasta semen. Besarnya susut karbonasi bervariasi bergantung pada proses susut pengeringan atau susut karbonasi yang terjadi dahulu. Jika terjadi bersamaan maka nilai susut akan lebih kecil.

\section{Metode ACI209.2R-08}

Metode untuk menghitung rangkak dan susut pada ACI209.2R-08 adalah sebagai berikut:

a. Rangkak

$$
V_{t}=\frac{t^{0.6}}{10+t^{0.6}} \times V_{u}
$$

dengan $\mathrm{V}_{\mathrm{t}}=$ Koefisien rangkak dalam waktu $\mathrm{t}$ (hari), $\mathrm{t}=$ Waktu setelah pengerasan awal, $\tau=$ Umur beton saat diberi beban, $\mathrm{V}_{\mathrm{u}}=$ Koefisien rangkak batas $\left(2,35 \mathrm{~K}_{\mathrm{C}}\right), \mathrm{K}_{\mathrm{c}}=$ Koefisien koreksi untuk rangkak apabila kondisi diluar standar.

$$
K_{c}=K_{A C} \times K_{R H} \times K_{P} \times K_{S} \times K_{A G} \times K_{A}
$$

dengan :

$\mathrm{K}_{\mathrm{AC}} \quad$ = faktor koreksi yang dipengaruhi umur beton saat pembebanan

$$
\begin{aligned}
& K_{A C}=1,25 \times \tau^{-0.118}, \text { untuk moist cured concrete } \\
& K_{A C}=1,13 \times \tau^{-0.095}, \text { untuk steam cured concrete }
\end{aligned}
$$

$\mathrm{K}_{\mathrm{RH}}=$ Faktor koreksi yang dipengaruhi oleh kelembaban relatif dengan nilai $\mathrm{H}$ dalam persen

$$
K_{R H}=1,27-0,0067 \times H, \text { untuk } \mathrm{H}>40 \%
$$

$\mathrm{K}_{\mathrm{P}} \quad=$ Faktor koreksi yang dipengaruhi rasio penampang (inchi)

$$
K_{P}=1,12-0,08 \times V / S
$$

$\mathrm{K}_{\mathrm{S}} \quad=$ Faktor koreksi yang dipengaruhi nilai slump beton $(\mathrm{mm})$

$$
K_{S}=0,82+0,00264 \times S
$$

$\mathrm{K}_{\mathrm{AG}}=$ Faktor koreksi yang dipengaruhi perbandingan agregat halus dengan total agregat $(\%)$

$$
K_{A G}=0,88+0,0024 \times \psi
$$

$\mathrm{K}_{\mathrm{A}} \quad=$ Faktor koreksi yang dipengaruhi oleh kadar udara $(\%)$

$$
K_{A}=0,46+0,09 \times A
$$

b. Susut

$$
\begin{gathered}
\varepsilon_{s h}=\frac{t}{35+t} \times \varepsilon_{s h u} ; \text { untuk t setelah } 7 \text { hari ( moist cured concrete) } \\
\varepsilon_{s h}=\frac{t}{55+t} \times \varepsilon_{\text {shu }} ; \text { untuk t setelah 1-3 hari ( steam cured concrete) }
\end{gathered}
$$

dengan $\varepsilon_{\mathrm{Sh}}=$ Regangan susut batas; $780 \times 10^{-6} . \mathrm{K}_{\mathrm{sh}}$ (in/in). Untuk kondisi diluar standart maka harus dikali dengan faktor koreksi.

$$
K_{s h}=K_{R H} \times K_{P} \times K_{S} \times K_{P C} \times K_{A G} \times K_{A}
$$

dengan :

$\mathrm{K}_{\mathrm{RH}}=$ Faktor koreksi akibat kelembaban relatif (\%)

$K_{H}=1,4-0,01 \times H$, untuk kelembaban relatif antara $40 \%-80 \%$

$K_{H}=3-0.03 \times H$, untuk lembaban relatif antara $80 \%-100 \%$

$\mathrm{K}_{\mathrm{P}} \quad=$ Faktor koreksi akibat rasio penampang (inchi)

$$
K_{P}=1,14-0,09 \times \mathrm{V} / \mathrm{S}
$$

$\mathrm{K}_{\mathrm{S}} \quad=$ Faktor koreksi akibat nilai slump $(\mathrm{mm})$

$$
K_{S}=0,89+0,00161 \times S 1
$$

$\mathrm{K}_{\mathrm{PC}} \quad=$ Faktor koreksi akibat kandungan semen $(\mathrm{kg} / \mathrm{m} 3)$

$$
K_{P C}=0,75+0,00061 \times c
$$


$\mathrm{K}_{\mathrm{AG}} \quad=$ Faktor koreksi akibat perbandingan agregat halus dengan total agregat

$$
\begin{aligned}
& K_{A G}=0,3+0,014 \times \psi, \text { untuk } \psi<50 \% \\
& K_{A G}=0,9+0,002 \times \psi, \text { untuk } \psi>50 \%
\end{aligned}
$$

$\mathrm{K}_{\mathrm{A}} \quad=$ Faktor koreksi akibat kadar udara $(\%)$

$$
K_{A}=0,95+0,008 \times A
$$

\section{Metode CEB-FIB MC90}

Metode menghitung rangkak susut pada CEB-FIB MC90 adalah sebagai berikut:

a. Rangkak

$$
\phi_{28(t, t 0)}=\phi_{0} \beta_{c(t, t 0)}
$$

dengan $\phi_{0}=$ koefisien rangkak notional, $\beta_{c(t, t 0)}=$ koefisien yang menunjukkan perkembangkan nilai rangkak dengan waktu setelah pembebanan, $\mathrm{t}=$ umur beton, $\mathrm{t} 0=$ umur beton saat pembebanan.

Koefisien rangkak notional bisa ditentukan dengan persamaan 22 sebagai berikut.

$$
\phi_{0}=\phi_{R H}(h) \beta_{(f c m 28)} \beta_{(t 0)}
$$

dengan :

$$
\begin{aligned}
\phi_{R H}(h)=[1 & \left.+\frac{1-h / h_{0}}{\sqrt[3]{0.1\left[(V / S) /(V / S)_{0}\right]}} \alpha_{1}\right] \alpha_{2} \\
\beta_{(f c m 28)} & =\frac{5,3}{\sqrt{f_{c m 28} / f_{c m 0}}} \\
\beta_{(t 0)} & =\frac{1}{0,1+\left(t_{0} / t_{1}\right)^{0,4}} \\
\alpha_{1} & =\left[\frac{3,5 f_{c m 0}}{f_{c m 28}}\right]^{0,7} \\
\alpha_{1} & =\left[\frac{3,5 f_{c m 0}}{f_{c m 28}}\right]^{0,2}
\end{aligned}
$$

dengan $f_{c m 28}=$ kuat tekan rata-rata beton saat umur $28(\mathrm{MPa}), f_{c m 0}=10 \mathrm{MPa}, \mathrm{h}=$ kelembaban relatif pada lingkungan dalam desimal, $\mathrm{h}_{0}=1, \mathrm{~V} / \mathrm{S}=$ perbandingan volum dengan luas permukaan $(\mathrm{mm}),(\mathrm{V} / \mathrm{S})_{0}=50$ $\mathrm{mm}, \mathrm{t}_{1}=1$ hari, $\mathrm{t}_{0}=$ umur beton saat diberi pembebanan, $\alpha 1 \& \alpha 2=$ koefisien yang dipengaruhi nilai kuat tekan rata rata beton.

Efek dari tipe sement dan temperatur curing pada koefisien rangkak dapat diperhitungkan dengan memodifikasi umur beton saat pembebanan $\left(\mathrm{t}_{0}\right)$ sebagai berikut.

$$
t_{0}=t_{0, T}\left[\frac{9}{2+\left(t_{0, T} / t_{t, T}\right)^{1.2}}+1\right]^{\alpha} \geq 0,5 \text { hari }
$$

dengan $\mathrm{t}_{0, \mathrm{~T}}=$ umur beton saat diberi pembebanan yang disesuaikan dengan temperatur beton (untuk $\mathrm{T}=20^{\circ} \mathrm{C}$ maka $\mathrm{t}_{\mathrm{o}, \mathrm{T}}$ dapat disamakan dengan $\mathrm{t}_{\mathrm{o}}$ ), $\mathrm{T}_{1, \mathrm{~T}}=1$ hari $\alpha=$ nilai yang ditentukan berdasarkan tipe semen; $\alpha=-1$ untuk slowly hardening cement; $\alpha=0$ untuk normal or rapidly hardening cement; $\alpha=1$ untuk rapid hardening cement.

Koefisien $\beta_{c(t, t 0)}$ menunjukkan perkembangan nilai rangkak terhadap waktu setelah beban diberikan yang nilainya dapat ditentukan dengan persamaan berikut.

$$
\beta_{c(t, t 0)}=\left[\frac{\left(t-t_{0}\right) / t_{t}}{\beta H+\left(t-t_{0}\right) / t_{t}}\right]^{0.3}
$$

Dengan :

$$
\begin{gathered}
\beta_{H}=150\left[1+\left(1,2 \times h / h_{0}\right)^{18}\right](V / S) /(V / S)_{0}+250_{\alpha 3} \leq 1500_{\alpha 3} \\
\alpha_{3}=\left[\frac{3,5 f_{c m 0}}{f_{c m 28}}\right]^{0.5}
\end{gathered}
$$

dengan $\mathrm{t}_{1}=1$ hari, $\mathrm{h}_{0}=1,(\mathrm{~V} / \mathrm{S})_{0}=50 \mathrm{~mm}, \alpha 3=$ koefisien yang dipengaruhi nilai kuat tekan rata-rata beton.

b. Susut 


$$
\varepsilon_{S H(t, t c)}=\varepsilon_{C S 0} \beta_{S}(t-t c)
$$

dengan $\varepsilon_{C S 0}=$ koefisien susut notional, $\beta_{s}(t-t c)=$ koefisien yang menyatakan perkembangan nilai susut dengan waktu pengeringan beton, $t=$ umur beton dalam hari, $t_{\mathrm{c}}=$ umur beton saat dimulainya pengeringan, $\left(t-t_{c}\right)=$ durasi pengeringan dalam hari.

Nilai koefisien susut notional dapat dihitunga dengan persamaan berikut

$$
\varepsilon_{C S O}=\varepsilon_{S}\left(f_{c m 28}\right) \beta_{R H}(h)
$$

dengan :

$$
\begin{gathered}
\varepsilon_{S}\left(f_{c m 28}\right)=\left[160+10 \beta_{S C}\left(9-f_{c m 28} / f_{c m 0}\right)\right] \times 10^{-6} \\
\beta_{R H}(h)=-1,55\left[1-\left(\frac{h}{h_{0}}\right)^{3}\right] ; \text { untuk } 0,4 \leq \mathrm{h}<0,99 \\
\beta_{R H}(h)=0,25 ; \text { untuk } \mathrm{h} \geq 0,99
\end{gathered}
$$

dengan $f_{\mathrm{cm} 28}=$ kuat tekan rata rata beton pada umur 28 hari $(\mathrm{MPa}), f_{\mathrm{cm} 0}=10 \mathrm{MPa}, \beta_{\mathrm{SC}}=$ koefisien yang dipengaruhi oleh tipe semen, $h=$ kelembaban relatif dalam desimal, $h_{o}=1$.

Perkembangan nilai susut dengan waktu dapat diperoleh dengan persamaan berikut

$$
\beta_{S}\left(t-t_{c}\right)=\left[\frac{\left(t-t_{v}\right) / t_{1}}{350\left[(V / S) /(V / S)_{0}\right]^{2}+\left(t-t_{c}\right) / t_{1}}\right]^{0.5}
$$

dengan $(t-t c)=$ durasi pengeringan, $\mathrm{t}_{\mathrm{t}}=1$ hari, $\mathrm{V} / \mathrm{S}=$ rasio perbandingan volume dan luas permukaan, dan $(\mathrm{V} / \mathrm{S})_{0}=50 \mathrm{~mm}$.

Metode ini mengasumsikan, periode curing beton tidak melebihi 14 hari pada temperatur normal, durasi dengan moist curing tidak berefek signifikan pada proses susut. Karenanya, parameter ini serta efek dari temperatur curing tidak diperhitungkan.

\section{Metode EN-1992-1-1-2004}

a. Rangkak

$$
\phi\left(t, t_{o}\right)=\phi_{0} \cdot \beta_{c\left(t, t_{o}\right)}
$$

dengan $\phi_{0}$ adalah koefisien rangkak notional dan persamaan untuk menentukannya adalah sebagai berikut.

dengan :

$$
\phi_{0}=\phi_{R H} \cdot \beta_{\left(f_{c m}\right)} \cdot \beta_{\left(t_{0}\right)}
$$

$\phi_{R H}=$ faktor kelembaban relatif pada koefisien rangkak dan persamaan untuk menentukannya dibagi menjadi 2 yaitu :

$$
\begin{gathered}
\phi_{R H}=1+\frac{1-R H / 100}{0,1 \cdot \sqrt[3]{h_{0}}} ; \text { untuk } f_{\mathrm{cm}} \leq 35 \mathrm{MPa} \\
\phi_{R H}=\left[1+\frac{1-R H / 100}{0,1 \cdot \sqrt[3]{h_{0}}} \cdot \alpha_{1}\right] \cdot \alpha_{2} ; \text { untuk } f_{\mathrm{cm}} \geq 35 \mathrm{MPa} \\
\beta\left(f_{c m}\right)=\frac{16,8}{\sqrt{f_{c m}}} \\
\beta\left(t_{0}\right)=\frac{1}{\left(0,1+t_{0}^{0,20}\right)} \\
h_{0}=\frac{2 * A_{c}}{u}
\end{gathered}
$$

dengan $f_{c m}=$ kuat tekan beton, $\mathrm{RH}=$ kelembaban relatif dalam persen, $\beta\left(f_{c m}\right)=$ faktor dari efek kekuatan beton terhadap rangkak, $\beta\left(t_{0}\right)=$ faktor dari efek umur beton, $\mathrm{h}_{0}=$ ukuran dari beton, Ac = luas penampang beton, $u=$ keliling beton yang terkontak langsung dengan atmosfer.

$$
\begin{gathered}
\beta c(t, t 0)=\left[\frac{\left(t-t_{0}\right)}{\left(\beta_{H}+t-t_{0}\right)}\right]^{0,3} \\
\beta_{H}=1,5\left[1+(0,012 R H)^{18}\right] \\
\beta_{H}=1,5\left[1+(0,012 R H)^{18}\right] h_{0}+250 \propto_{3} \leq 1500 ; \text { untuk } f_{\mathrm{cm}} \leq 35 \mathrm{MPa} \\
\propto_{1}=\left[\frac{35}{f_{c m}}\right]^{0,7} \text { untuk } f_{\mathrm{cm}} \geq 35 \mathrm{MPa} \\
\propto_{2}=\left[\frac{35}{f_{c m}}\right]^{0,2}
\end{gathered}
$$




$$
\propto_{3}=\left[\frac{35}{f_{c m}}\right]^{0,5}
$$

dengan $\beta c(t, t 0)=$ koefisien yang menunjukan perkembangan rangkak dengan waktu setelah diberi pembebanan, $t=$ umur beton, $t_{0}=$ umur beton saat terjadi pembebanan, $\beta_{H}=$ koefisien yang dipengaruhi kelembaban relatif dan ukuran beton, $\alpha=$ koefisien yang menunjukan kekuatan beton.

b. Susut

$$
\begin{gathered}
\varepsilon_{c d, 0}=0,85\left[\left(220+110 * \alpha_{d s 1}\right) \cdot \exp \left(-\alpha_{d s 2} \cdot \frac{f_{c m}}{f_{c m 0}}\right)\right] \cdot 10^{-6} \cdot \beta_{R H} \\
\beta_{R H}=-1,55\left[1-\left(\frac{R H}{R H_{0}}\right)^{3}\right]
\end{gathered}
$$

dengan $f_{c m}=$ kuat tekan beton, $f_{\mathrm{cm} 0}=10 \mathrm{MPa}, \alpha_{\mathrm{ds} 1}=$ koefisien yang bergantung dengan jenis semen; untuk kelas $\mathrm{S}$ digunakan 3; untuk kelas $\mathrm{N}$ digunakan 4; untuk kelas $\mathrm{R}$ digunakan 6 , $\alpha_{\mathrm{ds} 2}=$ koefisien yang bergantung dengan jenis semen; untuk kelas $\mathrm{S}$ digunakna 0.13 ; untuk kelas $\mathrm{N}$ digunakan 0.12 ; untuk kelas $\mathrm{R}$ digunakan $0.11, \mathrm{RH} \quad=$ kelembaban relatif, $\mathrm{RH}_{0}=100 \%$.

\section{METODE PENELITIAN}

\section{Data fisik jembatan}

1. Jenis jembatan

2. Panjang bentang

: Struktur Beton Prategang (Single Span)

3. Lebar jembatan : $60 \mathrm{~m}$

- Lebar lantai kendaraan

: $2 \times 3,5 \mathrm{~m}$

5. Lebar bahu jalan

$: 1 \mathrm{~m}$

6. Jenis gelagar

: Double Cellular Box girder

\section{Gelagar}

1. Sistem prategang

2. Mutu beton

: Beton prategang dengan sistem posttensioning

3. Berat jenis : $50 \mathrm{MPa}$

: $25 \mathrm{kN} / \mathrm{m}^{3}$

\section{Strand}

1. Jenis strand

: Seven Wire Strand ASTM A 416-06

2. Diameter nominal $(\mathrm{d})$

: $15,24 \mathrm{~mm}$

3. Luas nominal (Ap)

: $140 \mathrm{~mm}^{2}$

4. Tegangan leleh $\left(f_{p y}\right)$

: $1675 \mathrm{MPa}$

5. Tegangan putus $\left(f_{p u}\right)$

: $1860 \mathrm{MPa}$

6. Beban putus strand $\left(F_{p k}\right) \quad: 260,7 \mathrm{kN}$

7. Modulus elastisitas (Es) : $200000 \mathrm{MPa}$

Hasil Pradimensi box girder menggunakan spesifikasi jembatan diatas dapat dilihat pada Gambar 1. Dan untuk pemodelan jembatan dalam MIDAS dapat dilihat pada Gambar 2.

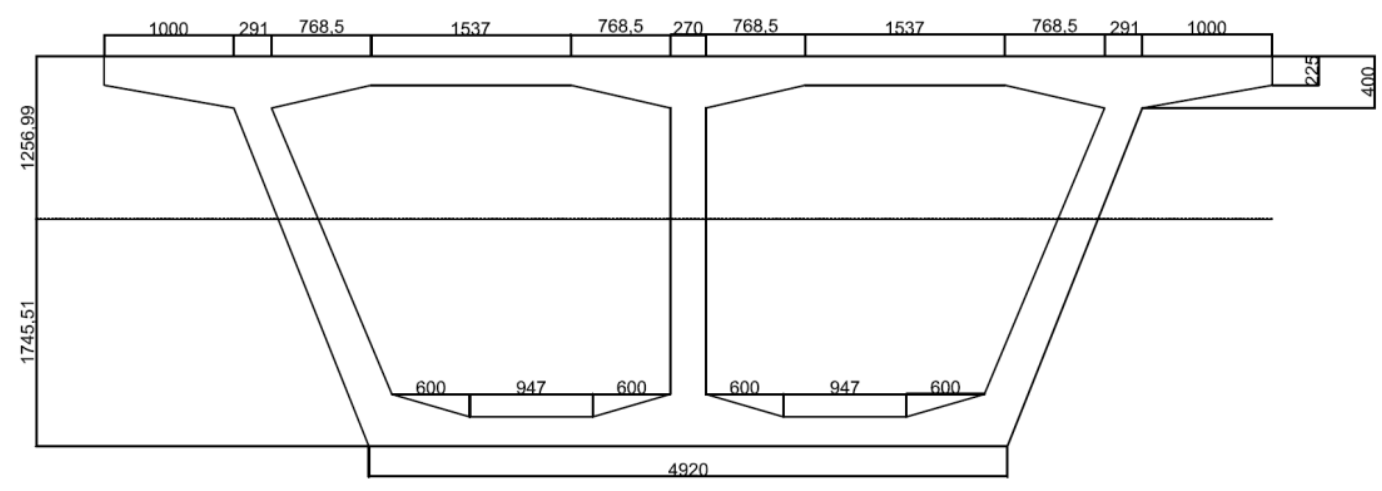

Gambar 1. Dimensi penampang box girder 


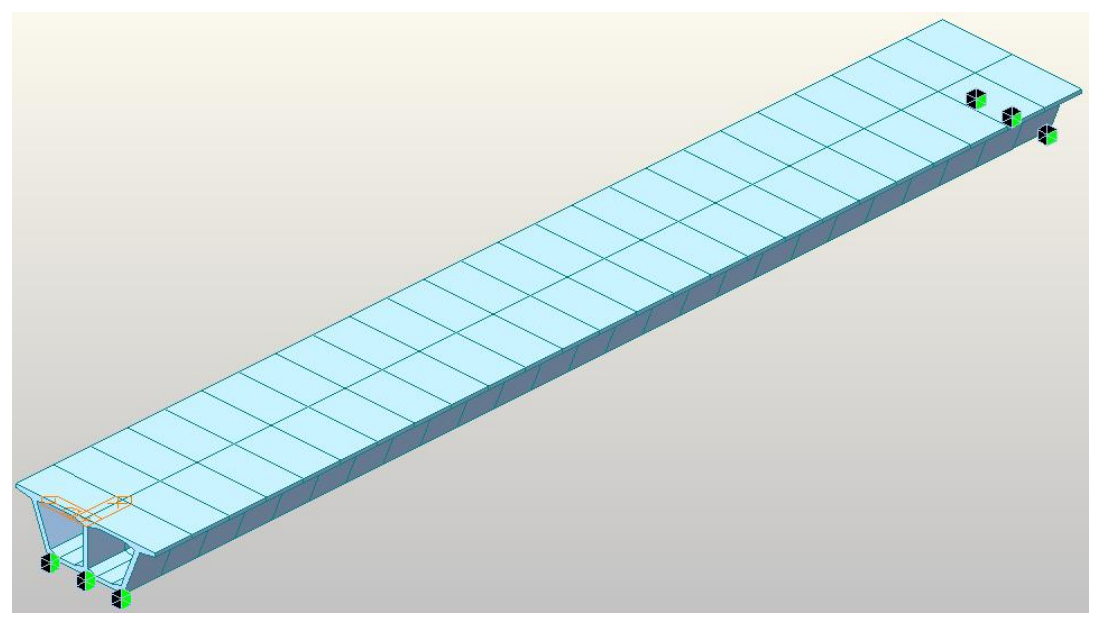

Gambar 2. Pemodelan jembatan single span di MIDAS

\section{Data input time dependent}

1) $\mathrm{ACI} 209.2 \mathrm{R}-08$

Dalam menghitung Creep dan Shrinkage di MIDAS 2020 menggunakan metode ACI209.2R-08, variabel yang dibutuhkan adalah sebagai berikut:

- Kuat tekan beton (fc')

: $50 \mathrm{MPa}$

- Kelembaban relatif (RH)

$: 70 \%$

- Volume-surface ratio (V/S)

: $80 \mathrm{~mm}$

- Umur beton saat awal shrinkage

: 7 hari

- Jenis curing

: moist cure

- Slump

: $100 \mathrm{~mm}$

- Persentase agregate halus

: $40 \%$

- Kadar udara

: $6 \%$

- Berat jenis semen

$$
\text { : } 3,8 \times 10^{-6} \mathrm{~N} / \mathrm{mm}^{3}
$$

2) CEB-FIB MC90

Dalam menghitung creep dan shrinkage di MIDAS 2020 menggunakan metode CEB-FIB MC90, variabel yang dibutuhkan adalah sebagai berikut :

- Kuat tekan beton (fc')

$: 50 \mathrm{MPa}$

- Kelembaban relatif (RH)

- Notional size of member

- Tipe semen

- Umur beton saat awal shrinkage

: Normal or rapid hardening

: 7 hari

3) $\mathrm{EN}-1992-1-1$

Dalam menghitung creep dan Shrinkage di MIDAS 2020 menggunakan metode EN-1992-1-1, variable yang dibutuhkan adalah sebagai berikut:

- Kuat tekan beton (fc')

$: 50 \mathrm{MPa}$

- Kelembaban relatif (RH)

- Notional size of member

- Jenis semen

: $\mathrm{N}$

- Umur beton saat awal Shrinkage

7 hari

\section{HASIL DAN PEMBAHASAN}

\section{Pembebanan}


1. Beban sendiri

Beban box girder $=\mathrm{A} \times \mathrm{Bj}=6,04665 \mathrm{~m}^{2} \times 25 \mathrm{kN} / \mathrm{m}^{3}=151,1662 \mathrm{kN} / \mathrm{m}$

2. Beban mati tambahan

Perhitungan beban mati tambahan meliputi beban aspal, beban genangan air hujan, beban lampu jalan, dan beban railing.

- Beban aspal

- Beban genangan air hujan

- Beban lampu jalan

- Beban railing

Total beban mati tambahan

$$
\begin{aligned}
& =\mathrm{b} \times \mathrm{h} \times \mathrm{BJ}=9 \mathrm{~m} \times 0,05 \mathrm{~m} \times 22 \mathrm{kN} / \mathrm{m}^{3} \\
& =9,9 \mathrm{kN} / \mathrm{m} \\
& =\mathrm{b} \times \mathrm{h} \times \mathrm{BJ}=9 \mathrm{~m} \times 0,05 \mathrm{~m} \times 9.8 \mathrm{kN} / \mathrm{m}^{3} \\
& =4,41 \mathrm{kN} / \mathrm{m} \\
& =0,1 \mathrm{kN} / \mathrm{m} \\
& =1 \mathrm{kN} / \mathrm{m} \\
& =15,41 \mathrm{kN} / \mathrm{m}
\end{aligned}
$$

\section{Beban hidup}

Perhitungan beban hidup lalu lintas meliputi beban terbagi rata (BTR) dan beban garis terpusat (BGT).

Contoh perhitungan beban hidup akibat beban lajur D pada bentang $60 \mathrm{~m}$.

Faktor Beban Dinamis $=0,525-0,0025 \mathrm{~L}=0,525-0,0025$ x $60=0,375$

Intensitas $\mathrm{BTR}=\mathrm{q}=6,75 \mathrm{kPa} \times 7 \mathrm{~m}=47,25 \mathrm{kN} / \mathrm{m}$

$\mathrm{BGT}=\mathrm{p}=49 \mathrm{kN} / \mathrm{m} \times 7 \mathrm{~m} \times 1,375=471,625 \mathrm{kN}$

\section{Hasil perhitungan momen}

Dari hasil analisis pada MIDAS, berikut adalah reaksi perletakan dan momen maksimum yang dihasilkan.

1. Reaksi Perletakan

- Dead Load : 4535,1 kN

- Superimposed Dead Load

: $462,3 \mathrm{kN}$

- Live Load : $1665,3 \mathrm{kN}$

2. Momen Maksimum

- Dead Load : $68024,8 \mathrm{kNm}$

- Superimposed Dead Load : 6934,5 kNm

- Live Load : $28336,9 \mathrm{kNm}$

\section{Kuat tekan beton}

- Kuat tekan beton prategang (f'c) = $\quad 50 \mathrm{MPa}$

- Kuat tekan beton saat transfer (f'ci) $=37,5 \mathrm{MPa}$

\section{Tegangan ijin beton}

a. Pada saat keadaan awal sebelum mengalami kehilangan gaya prategang (kondisi transfer)

- $\quad$ Tegangan ijin tekan $=-0.6 \times \mathrm{f}^{\prime} \mathrm{ci}=-22,5 \mathrm{MPa}$

- $\quad$ Tegangan ijin tarik $=0.25 \sqrt{\mathrm{f}^{\prime} \mathrm{ci}}=1,5309 \mathrm{MPa}$

\section{Menghitung kebutuhan strand}


Dari perhitungan didapatkan gaya $\mathrm{F}_{\mathrm{e}}$ sebesar $50601,0663 \mathrm{kN}$ dengan asumsi telah kehilangan gaya prategang sehingga $\mathrm{F}_{\mathrm{e}}=60 \% \mathrm{UTS}$

$$
\mathrm{n}=\frac{50601.06063 \times 10^{3}}{0.6 \times 1860 \times 140}=323,86 \text { strand }=325 \text { strand }
$$

Digunakan 18 tendon dengan 1 tendon berisi 19 strand, maka jumlah strand yang akan digunakan sebanyak 342 strands. Untuk desain tendon pada daerah tumpuan dan lapangan dapat dilihat pada Gambar 3 dan Gambar 4.

\section{Letak koordinat tendon}

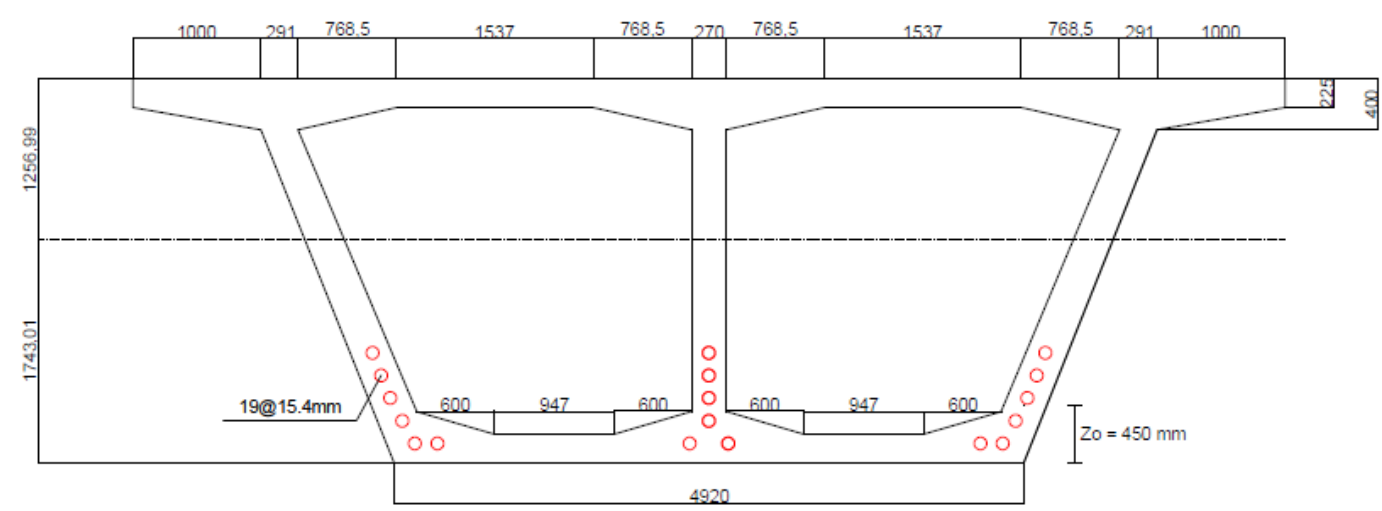

Gambar 3. Desain tendon pada tengah bentang

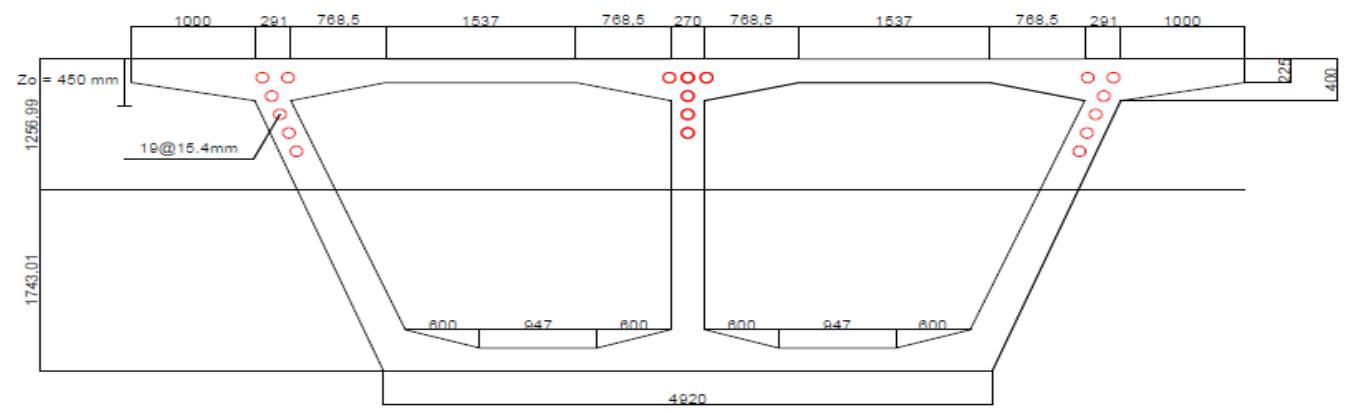

Gambar 4. Desain tendon pada tepi bentang

\section{Kapasitas momen}

Dari perhitungan kapasitas momen, didapatkan besar momen nominal $\left(\mathbf{M}_{\mathrm{n}}\right)$ adalah sebesar $191810,338 \mathrm{kNm}$. Maka besar $\phi \mathrm{M}_{\mathrm{n}}$ adalah $153448.3104 \mathrm{kNm}$

$$
M u=\gamma D L \times M D L+\gamma S D L \times M S D L+\gamma L L \times M L L
$$

Besar momen ultimate yang didapatkan dari rumus diatas adalah $146505,18 \mathrm{kNm}$

Sehingga, $\mathrm{Mu} \leq \phi \mathrm{M}_{\mathrm{n}}(\mathrm{OK})$

\section{Besar koefisien rangkak dan susut}

Hasil rekapitulasi nilai rangkak dan susut pada hari ke-10000 dengan metode ACI209.2R-08, CEB-FIP MC90 dan EN-1992-1-1 dapat dilihat pada Tabel 1. 
Tabel 1. Rekapitulasi nilai rangkak dan susut pada hari-10000

\begin{tabular}{ccc}
\hline Metode & Nilai Susut & Nilai Rangkak \\
\hline ACI209.2R-08 & $-4,0144 \times 10^{-4}$ & 1,5989 \\
CEB-FIB MC90 & $-3,9043 \times 10^{-4}$ & 1,779 \\
EN 1991-1-1 & $-2,8233 \times 10^{-4}$ & 1,6933 \\
\hline
\end{tabular}

\section{Hasil tegangan dan lendutan pada jembatan}

Dalam penelitian ini, hasil tegangan akan diperhitungan saat post construction stage. Sedangkan hasil lendutan akan diperhitungkan pada kondisi construction stage 1 (hari ke 7), Construction stage 2 ( hari ke 30) dan Construction Stage 3 (hari ke 10000). Semua hasil tegangan dan lendutan akan dibandingkan dalam 3 metode berbeda yang dapat dilihat pada Tabel 2 dan Tabel 3. Lalu untuk grafik lendutan dapat dilihat pada Gambar 5. Untuk perjanjian tanda + dan - digunakan sebagai berikut:

- Tegangan (+) : Tegangan tarik

- Tegangan (-) : Tegangan tekan

- $\quad$ Lendutan (+) : Defleksi keatas

- $\quad$ Lendutan (-) : Defleksi kebawah

Tabel 2. Hasil tegangan dengan menggunakan metode ACI209.2R-08, CEB-FIB MC90 dan EN-1992-1-1

\begin{tabular}{ccccccc}
\hline \multirow{2}{*}{ Jenis Beban } & \multicolumn{2}{c}{$\begin{array}{c}\text { Tegangan }(\mathrm{MPa}) \\
\text { Metode ACI209.2R-08 }\end{array}$} & \multicolumn{2}{c}{$\begin{array}{c}\text { Tegangan (MPa) Metode } \\
\text { CEB-FIB MC90 }\end{array}$} & \multicolumn{2}{c}{ Tegangan (MPa) } \\
& \multicolumn{2}{c}{ Metode EN-1992-1-1 } \\
\cline { 2 - 7 } & Bawah & Atas & Bawah & Atas & Bawah & Atas \\
\hline $\begin{array}{c}\text { Berat Sendiri } \\
\text { Beban Mati }\end{array}$ & 14,18320 & $-13,259$ & 14,1579 & $-10,748$ & 14,0748 & $-10,739$ \\
Tambahan & 1,44590 & $-1,3386$ & 1,4433 & $-1,0959$ & 1,4348 & $-1,0948$ \\
$\quad$ Gaya & & & & & & \\
Prategang & $-23,9778$ & 2,12520 & $-24,0018$ & 2,1204 & $-23,8459$ & 2,1048 \\
Beban Hidup & 5,9085 & $-4,4780$ & 5,8977 & $-4,479$ & 5,8631 & $-4,47360$ \\
Total & $-2,44020$ & $-14,1821$ & $-2,5029$ & $-14,2008$ & $-2,4732$ & $-14,2025$ \\
\hline
\end{tabular}

Tabel 3. Hasil lendutan dengan menggunakan metode ACI209.2R-08, CEB-FIB MC90 dan EN-1992-1-1

\begin{tabular}{cccc}
\hline \multirow{2}{*}{ Waktu (hari) } & \multicolumn{3}{c}{ Metode Analisis } \\
\cline { 2 - 4 } & ACI209.2R-08 & CEB-FIB MC90 & EN-1992-1-1 \\
\hline 7 & $-0,018 \mathrm{~m}$ & $-0,016 \mathrm{~m}$ & $-0,017 \mathrm{~m}$ \\
30 & $-0,028 \mathrm{~m}$ & $-0,026 \mathrm{~m}$ & $-0,026 \mathrm{~m}$ \\
10000 & $-0,054 \mathrm{~m}$ & $-0,051 \mathrm{~m}$ & $-0,049 \mathrm{~m}$ \\
\hline
\end{tabular}




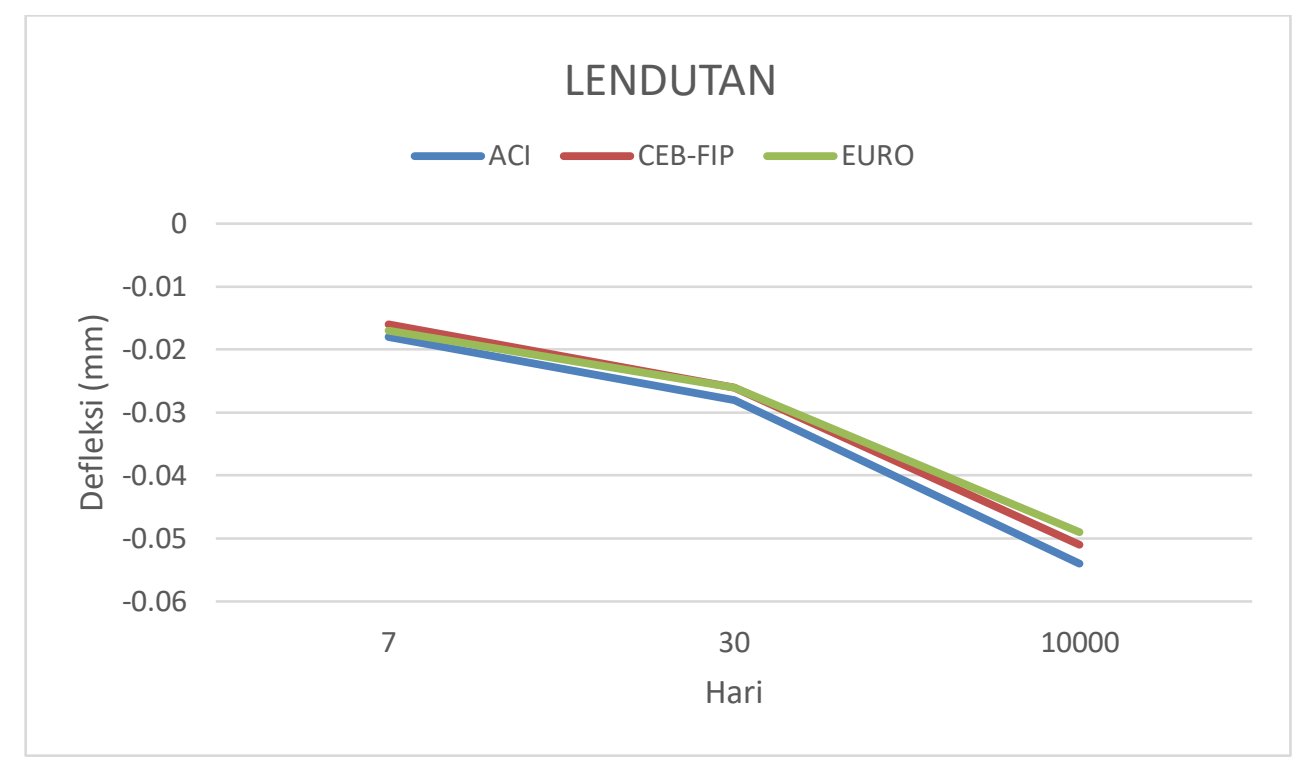

Gambar 5. Grafik perbandingan lendutan yang terjadi dari 3 metode

\section{KESIMPULAN DAN SARAN}

\section{Kesimpulan}

Berdasarkan hasil analisis yang telah dilakukan dengan menggunakan ketiga metode yaitu ACI209.2R-08, CEBFIB MC90 dan EN-1992-1-1-2004. Kesimpulan yang dapat diambil adalah sebagai berikut:

1. Perhitungan nilai rangkak dengan menggunakan 3 metode menghasilkan nilai berturut-turut sebagai berikut 1,5989, 1,779 dan 1,6933. Dalam 10000 hari, nilai rangkak yang dihasilkan oleh ketiga metode sudah mencapai ultimate dan perubahan nilai setelahnya mendekati konstan.

2. Perhitungan nilai susut dengan menggunakan 3 metode menghasilkan nilai berturut-turut $-4,0144 \times 10-4$, 3,9043x10-4 dan -2,8233x10-4. Dalam 10000 hari, nilai susut yang dihasilkan ketiga metode sudah mencapai nilai ultimate dan perubahan nilai setelahnya mendekati konstan

3. Tegangan yang diperoleh dari ketiga metode tersebut memiliki hasil yang identik satu sama lain. Tegangan serat atas dan serat bawah yang diperoleh juga masuk dalam persyaratan tegangan ijin.

4. Lendutan yang terjadi pada 10000 hari masih terdapat dalam batas ijin yaitu $-0.054 \mathrm{~mm}$

5. Dalam hasil analisis ini, penulis juga mengambil kesimpulan bahwa penggunaan ketiga metode tersebut akan menghasilkan hasil yang serupa jika komponen variabel yang dipakai juga sama, seperti : relative humidity, notional size, volume surface ratio, jenis semen, kandungan agregat dan dimensi jembatan.

\section{Saran}

Berdasarkan hasil penelitian maka saran untuk analisis adalah sebagai berikut:

1. Untuk analisis berikutnya mungkin bisa diberikan kombinasi beban yang lain seperti memperhitungkan beban gempa, beban angin, dan temperatur.

2. Untuk penelitian berikutnya mungkin bisa menggunakan jembatan beton komposit sebagai pembanding.

3. Untuk Penelitian berikutnya dapat dicoba dengan membandingkan kelembaban relatif di setiap daerah karena kelembaban relatif sangat berpengaruh pada koefisien rangkak dan susut.

\section{DAFTAR PUSTAKA}

American Concrete Institute. ACI209.2R-08 Prediction of Creep, Shrinkage, and Temperature Effects in Concrete Structures. America, 2008.

Badan Standardisasi Nasional. RSNI-T-02-2005 Standar Pembebanan untuk Jembatan. Indonesia: RSNI, 2005.

Badan Standardisasi Nasional. "RSNI-T-12 Perencanaan Struktur Beton Untuk Jembatan.” SNI (2004).

European Standard. EN-1992-1-1 Design of Concrete Structures. 2004.

International Federation for Structural Concrete. CEB-FIB MC90. 1990.

MIDAS. http://manual.midasuser.com/EN_Common/Civil/890/index.htm. 1989. Document. 2020.

Supriyadi, Bambang dan Agus Setyo Muthohar. Jembatan. Yogyakarta: UGM, 2007. 
